AN EXPERIMENTAL STUDY OF THE RELATION OF THE NERVOUS SYSTEM TO THE DEVELOPING MUSCULATURE IN THE EMBRYO OF THE FROG.

BY

ROSS GRANVILLE HARRISON, Ph. D., M. D.,

Associate Professor of Anatomy, The Johns Hopkins University, Baltimore

With 18 Text Figures.

While the rôle of the nervous system in development has been studied with increasing interest in recent years, the data are as yet of such a varied and conflicting nature as to preclude the possibility of satisfactory generalizations. The following pages are therefore offered as a contribution to one phase of this subject, in the hope that through the study of comparatively simple particular problems we may advance towards some general conclusion. ${ }^{1}$

The influence of the nervous system on the regeneration of lost parts has formed the subject of several experimental studies. Herbst, 99, and or, has shown that in the decapod crustacea, the optic ganglion is an essential factor in determining the character of the appendage regenerated after the amputation of the eye. Morgan, or, has reported experiments, showing that it is the presence of the nerve cord at the cut end of a decapitated earthworm that determines the regeneration of a new head. In planarians, according to Bardeen, 02 and 03 , the stimulus to the regeneration of a new head arises from the cut surface of the central nervous system. Barfurth, 02, and Rubin, 03, have investigated the effect of injury to the nervous system upon the regeneration of the tail and limbs in the amphibia, concluding that the destruction of the spinal cord and brain has no deterrent effect upon the development of a new appendage. In the case of the limbs, according to the same investigators, regeneration begins normally even when the nerves running to the stump

${ }^{1}$ A brief account of this work was given in a paper read before the Association of American Anatomists at Washington, D. C., December 30, 1902. HABRIsoN, 03, On the Differentiation of Muscular Tissue When Removed from the Influence of the Nervous System. Proc. Assoc. Amer. Anat., p. IV, Amer. JoURNAL OF ANATOMY, Vol. II.

AMERICaN JOURAal OF ANatomy.-VOL. III. 
are destroyed, although later the absence of nervous influences, or perhaps the lacking function, tends to retard the processes and ultimately brings them to a standstill. Wolff, o2, has made somewhat similar experiments upon the axolotl, and concludes that the nervous system does exercise a morphogenetic function in the regeneration of the limbs.

The data are more meagre concerning the nervous regulation of purely ontogenetic processes. Loeb, 96, was the first to study this question experimentally; he showed that the metamorphosis takes place simultaneously in the posterior and anterior portions of the amblystoma larva even after the spinal cord has been severed. Later it was shown by Schaper, 98, that the frog embryo develops normally after the removal of the entire brain.

A considerable mass of evidence having a bearing upon this question, has been collected from the study of acephalic and amyelic monsters. This evidence is, however, conflicting and the same facts have not always been interpreted in like manner by all investigators. Leonowa, 93, and Fraser, 95, have on the one hand described human fotus in which brain and spinal cord were totally lacking, while the peripheral sensory nerves and the musculature were normally developed. On the other hand, E. H. Weber, 51, Neumann, or, and others have described cases in which absence of certain portions of the central nervous system has been accompanied by total absence of musculature in the region normally supplied by the lacking nerves, although skeleton, blood vessels and even tendons were normally developed.

The discussion has centered especially around the question of the dominance of the differentiation of the voluntary musculature by the nervous system. Neumann, oI, has given a critical résumé of the facts bearing upon this question. He concludes that in cases similar to those described by Leonowa and Fraser, where there is a well-developed muscular system in spite of the total absence of the brain and cord, the nervous system must have developed in the early stages of embryonic life up to a certain point, and that it did not undergo degeneration until after the differentiation of the muscular system had taken place. Thus in his effort to harmonize the seemingly conflicting observations referred to above, Neumann $^{2}$ reaches the conclusion that the physiological relations between muscle and nerve change during the course of the development of the individual as follows:

1. The first development of the muscles takes place under the influence of the nervous system and through the agency of the motor nerves, which

${ }^{2}$ Op. cit., p. 463 . 
grow from the latter into the muscle. Self-differentiation of the muscles does not take place.

2. After the muscles have arisen, their nourishment and further growth during the embryonic period takes place independently of the central nervous system; they have, so to speak, emancipated themselves from the influence of the latter.

3. Not until the post-embryonic life is reached is the dependence again established; the trophic centers of the spinal cord and brain then begin action.

Herbst, or, analyzes the same data, however, and maintains that it is the sensory nerves including the cells of the spinal ganglia, and not the motor nerves, that are necessary to stimulate the differentiation of the muscular substance in the embryo. Herbst finds support for this view in Wolff's observations referred to above and also in the fact that in Leonowa's case, as well as in others, the spinal ganglia and sensory nerves alone were present. Herbst and Neumann agree, nevertheless, in holding that the nervous system exerts a formative influence upon the muscular tissue. The well-known fact that a muscle undergoes atrophic changes after its nerve supply has been cut off, would, at first sight, uphold this view. The study of normal development likewise affords some evidence which might also be interpreted as lending support to it, though it does not necessarily do so. In the embryos of lower vertebrates, for instance, the connection of the motor spinal nerves with the muscle plates is established just at the time when the contractile substance begins to be laid down. ${ }^{3}$ Again, as Nussbaum, 94 (also later publications), has shown in a series of investigations, there is a close parallel between the direction of the intramuscular ramifications of the nerve supplying a muscle and the airection of the growth of that muscle in the embryo, a view which has also been supported by Bardeen, oo. Nusbaum, 02, points out, however, that this correspondence might exist even though there be no dependence on the part of the muscle upon a formative stimulus.

It is clear from the foregoing that the facts are insufficient to determine even the comparatively simple relations between the nervous system and the developing musculature. The difficulty in interpreting correctly the meaning of the teratological cases, which have been the subject of so much discussion, rests upon our inability to find out the exact nature of the original lesion. The only way to control satisfactorily this factor is

\footnotetext{
${ }^{3}$ This apparently does not hold for all vertebrates, for, according to Bardeen, $\infty$, the musculature of the pig embryo is differentiated to a considerable degree before the nerves establish a connection with it.
} 
by direct experimentation, but in devising experiments for this purpose it is necessary to formulate clearly just what is to be determined, for it is obvious from the facts already referred to, that the nervous system may possibly exert its influence in a variety of ways.

The first questions which I had in mind in beginning the present investigation were the comparatively simple ones whether a stimulus from the nervous system is necessary in order to start the differentiation of striated muscle fibers and whether the musculature is dependent upon the nervous system in its further development, including the grouping of the fibers into individual muscles. It is the first question that has of late been most freely discussed and has been answered affirmatively by Neumann and Herbst; even Rubin emphasizes the fact that of all the tissues in the regenerating limb the voluntary muscle is the most dependent upon the integrity of the nerves. While on the other hand Schaper's experiments do show that the central nervous system has no general directive action upon the development of the frog, they do not answer the first question just stated, for Schaper removed only the brain, leaving the spinal cord intact; and besides, embryos $6 \mathrm{~mm}$. long with welldereloped tail were used; in such embryos the motor nerve roots have already established connection with the muscle plates and the differentiation of the contractile substance is begun. The musculature at the time of experimentation in Schaper's experiments would thus fall into the second period of Nelmann. To test this question it is necessary to remove the spinal cord at a period of development, before there are traces of peripheral nerve fibers or contractile substance in the musculature. A series of experiments of this kind is described below in the first section.

Another question which may to advantage be considered in connection with that of the formative influence of the nervous system, is whether the normal processes of ontogeny are regulated by functional stimuli, or to state a more particular phase of the problem, whether the normal exercise of function is a necessary factor in determining the early course of development of the musculature. While the first series of experiments may be used in this connection, the necessary mutilation of the embryo enters as a disturbing factor. This question may be best tested experimentally by causing the suspension of muscular function in developing embryos through the action of a drug. Acetone chloroform is exceedingly well adapted to this purpose. In the second section of the present paper the results of rearing embryos in solutions of this substance are given. 


\section{Description OF the EXPERIMENTS.}

The experiments described below were made upon the embryos of Rana sylvatica, $R$. virescens and $R$. palustris, for the most part in the spring of 1902. As already emphasized, it was necessary for the purposes in view to work with embryos in which there were no traces of histological differentiation in the nervous or muscular systems. It was found on examination of serial sections of normal embryos that the oldest stage which safely fulfills this requirement is when the tail bud is just beginning to be perceptible. Sylvatica embryos (Fig. 1) are then about 3.7 $\mathrm{mm}$., virescens about $2.25 \mathrm{~mm}$., and palustris about $2.9 \mathrm{~mm}$. in length, although, owing to the considerable variation in the size of embryos of the same species, these measurements are to be regarded merely as roughly approximate. There are absolutely no nerve fibers in the central nervous system of these embryos and there are no traces of any peripheral nerves. The tissue of the myotomes consists of rounded cells somewhat flattened on their sides. About ten somites are distinctly marked off. The rest of the axial mesoderm is unsegmented.

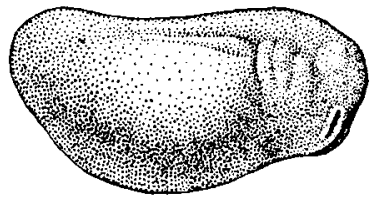

FIG. 1. Embryo of R. sylvatica, to show the stage of development used in the beginning opment used in the beginn
of the experiments. $\times 91_{/ 22}$.

\section{On the Effect of Removal of the Spinal Cord upon the Development of the Axial Musculature.}

The embryos of $R$. palustris are somewhat better adapted for this experiment than the other species. In the former the axis of the trunk is straight, while in embryos of $R$. sylvatica the dorsal curvature is marked. Virescens embryos are more difficult to operate upon on account of their smaller size.

The embryo is laid on its side in a shallow dish lined with cork or paper

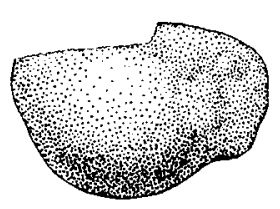

Fia. 2. Embryo of R. palustris immediately after the removal of the spinal cord.

sible to cut just between the medullary tube and the notochord, leaving the latter intact. One must count upon a number of failures, but salt solution. With a small sharp scalpel a narrow strip extending from the region of the pronephros to the tip of the tail is then cut off from the back of the embryo (Fig. 2). This strip contains the medullary tube, including the ganglion crest as far as it is developed, the dorsal portion of the myotomes and the unsegmented mesoderm, and also the dorsal fin fold. With some practice it is posand containing fresh water or dilute ( 0.2 per cent) 
fortunately it is possible to see immediately after making the cut just what has been removed, for in successful cases, on examining the wound surface with a lens, the notochord stands out as a distinct rod with the myotomes arranged alongside (Fig. 4). The operation may also be done successfully with a sharp, fine pair of scissors. In some experiments the thin strip of tissue containing the spinal cord was cut off entirely (Fig. 2); in others it was left hanging at its anterior end, but prevented from healing again to the main portion of the embryo (Fig. 4).

The embryos were kept after the operation in ordinary tap water or placed for a day or two in dilute salt solution, which insures a somewhat more rapid and perfect healing of the wound. 'This usually takes place, however, without difficulty in any case and even in two or three hours the wound is usually closed. As a control to the study of the further development, normal embryos of the same age were kept side by side with those which had been operated upon, and specimens of each were preserved from time to time for the purpose of studying their internal development.

As regards their external form, the embryos develop in the best instances normally except for the defect produced directly by the operation.

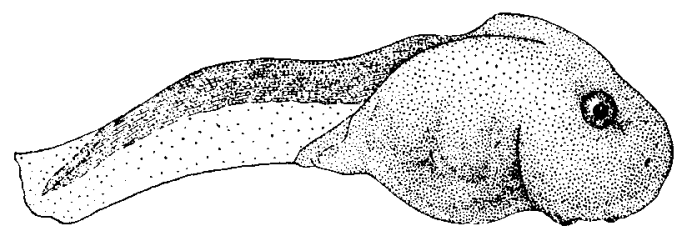

FIG. 3. Palustris larva six days after excision of the spinal cord as in Fig. 2 . $\times 9^{1 / 2}$.

Their development is, however, considerably retarded, not only in the region of the trunk and tail but also in the head where the nervous system was left intact. The individuals differ from one another considerably, owing, no doubt, to slight differences in the amount of tissue originally cut away. In the most favorable cases (Fig. 3) the tail is almost straight and shows only a lack of the dorsal part of the axis and the dorsal fin, but as a general rule the tail acquires a marked dorsal bend (Fig. 6), especially in sylvatica larvæ. In other cases, when the notochord has been injured, considerably greater deformity arises; this manifests itself in the crumpling and shortening of the tail, or sometimes even in its almost complete atrophy.

One rather remarkable feature, which shows itself constantly, is the presence of a small portion of the dorsal fin at the tip of the tail (Figs. 3 and 6). Microscopic examination shows that a small portion of the medullary tube is also present at that point. The development of these 
structures, lying dorsal to the axis of the tail assumes in some instances considerable proportions. When it is considered that everything dorsal to the notochord was removed by the operation, it is clear that this portion of the medullary tube must have regenerated in an anterior direction from the walls of the neurenteric canal.

The series of drawings (Figs. 4-6), made from one embryo at different stages of its development, gives an idea of the development of the individual. The first cut (Fig. 4 ) shows the embryo just after the operation. In this case the strip containing the spinal cord was left hanging to the head. The second stage (Fig. 5) is one day older. Here the tail shows a distinct dorsal flexure, due probably to the fact that the distal end of the notochord had been cut out, and considerable growth had taken place before the complete regeneration of the notochord oc-

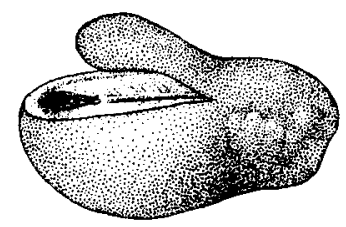

Fig. 4. Sylvatica embryo immediately after cutting the spinal cord. $\times 91 / 2$. curred. The cut edge of the small dorsal strip has also healed over and is beginning to coil up in a horizontal plane. Six days after the operation the larva appeared as in Fig. 6. The tail is normally expanded, but still shows the marked dorsal flexure. The small strip of tissue resting on the back has coiled itself up; the dorsal fin belonging to it is well developed. The larva is odematous and the lymph sinuses are much dilated. This condition is not uncommon in such specimens. Examined more carefully under moderate powers of magnifi-

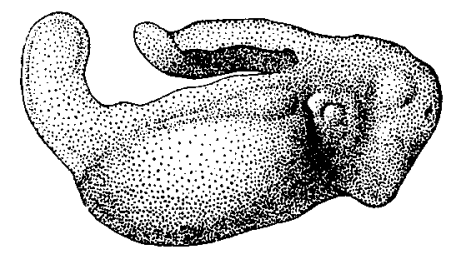

FIa. 5. Same specimen as in Fig. 4, one day after the operation. $\times \mathbf{9}_{1 / 2}^{1}$. cation, the arrangement of the muscle plates in the tail is found normal. The individual segments are V-shaped as usual, although the dorsal arm is shortened by the amount removed by the operation. The primary abdominal muscle is also present and extends anteriorly from the myotomes at the base of the tail, spreading out into a thin sheet in the abdominal walls.

The physiological differences between the embryos experimented upon and the normal ones are marked. While the latter soon acquire the power of movement and respond readily to stimuli, the former remain motionless even when stimulated strongly, except for the movements in several anterior myotomes where the cord had been left in connection with the body. In certain cases the tail exhibited independent twitching movements; in these cases a considerable stretch of the spinal cord was found 
to be present. They were, of course, rejected as being open to the suspicion that the nervous influences had not been entirely eliminated. In none of the larvæ without spinal cord was there ever any response to the direct mechanical stimulation of the muscles to be observed with certainty. On the other hand, in the one case ( $R$. palustris) in which electrical stimulation was tried, a marked local contraction of the axial musculature at the root of the tail followed the application of the electrodes at that point. This indicates that the musculature in these instances is capable of functioning. The case is, however, not quite con-

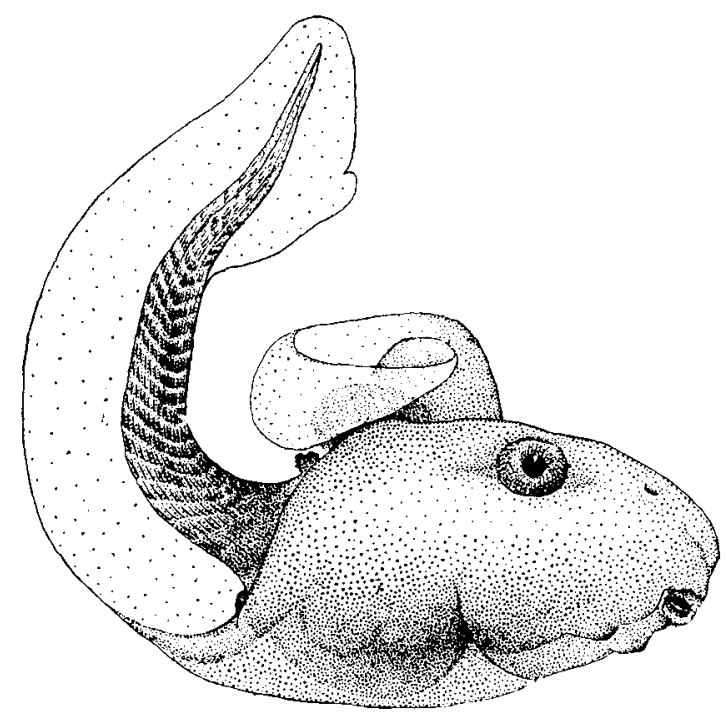

Fia. 6. Same specimen as in Fig. 4. Six days after the operation. $\times 91_{2}$. clusive, because no complete microscopic examination was made, the specimens having been severely injured during the stimulation.

The examination of specimens in serial sections demonstrates clearly that the effect of the operation is to remove permanently the spinal cord from the greater part of the trunk and tail. Only the small portion at the tip of the tail is present. This part of the medullary cord is, however, in normal as well as in injured specimens, merely an epithelial tube containing no ganglion cells and giving rise to no peripheral nerve fibers. No regeneration of cells takes place from the anterior portion of the cord. The cut end is found to be rounded off and the ventricle entirely closed. The nerve fibers constituting the longitudinal bundles extend, however, in all cases examined, for a considerable distance beyond the limits of the cord. They leave its posterior end and pass in a caudal direction through the mesenchyme occupying the small space bounded by the myotomes, notochord and epidermis. These bundles are thick and very distinct as they emerge from the cord; sometimes they break up into small bundles and in several instances distinct fasciculi could be traced into the lateral branch of the vagus. The bundles gradually become thinner as 
they extend further from the medullary cord and finally terminate altogether. Their exact mode of ending could not be determined. Distal to the point of termination of these intrinsic fibers of the cord there are no nerves of any description in the organism, except sometimes the $r$. lateralis vagi, which, as has been shown, grows out from the vagus ganglion, a structure not affected by the operation. The sense organs of the lateral line are also present in such cases. Spinal ganglia are, as would

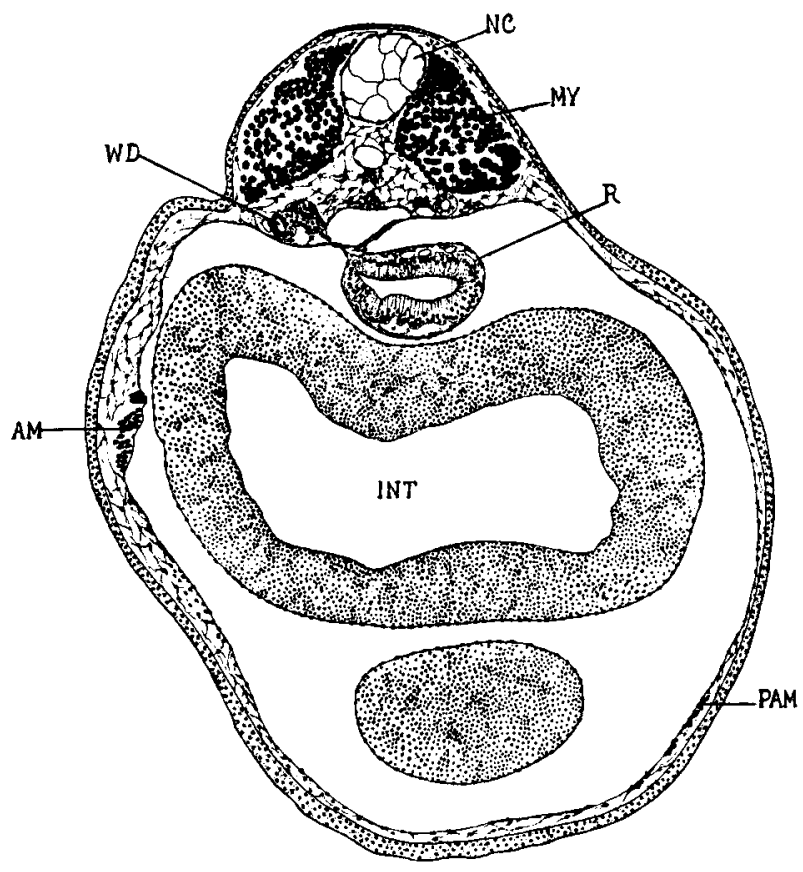

FIt. 7 .

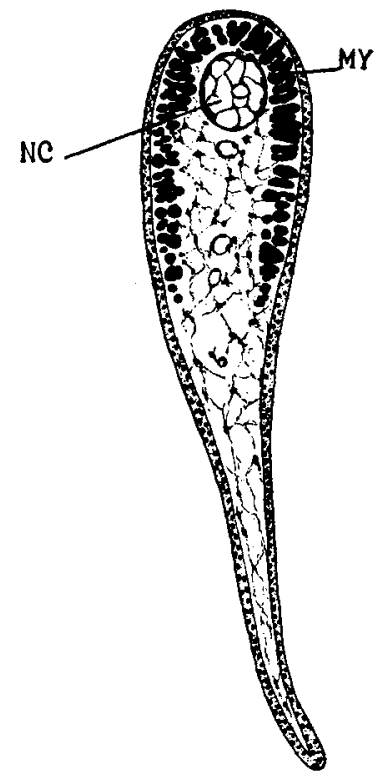

FIG. 8.

Fic. 7. Transverse section through the posterior part of the trunk of the specimen shown in Fig. 3 ; int, intestine; $n c$, notochord; $m y$, myotome; p. a. m., primary abdominal muscle; $r$, rectum; $w d$, Wolffian duct. $\times 50$.

FIG. 8. Transverse section through the tail of the specimen shown in Fig. 3. my, myotome; nc, notochord. $\times 50$.

be expected, absent from the entire region distal to the cut end of the medullary cord. In those cases in which the small dorsal strip containing the spinal cord was not cut off, but left attached by its anterior end to the head of the embryo, the longitudinal bundle fibers remain entirely within the walls of the cord and no free nerve fibers whatever are to be found in that part of the embryo where the immediate connection with the cord is severed.

' Cf. Harrison, oza. 
The general arrangement of the organs of the trunk and tail is well shown in cross sections (Figs. 7 and 8 ) of the specimen represented in Fig. 3, which was preserved six days after the operation. The absence of the dorsal fin and the medullary cord is striking. The notochord, which is normally developed, lies almost immediately below the epidermis in the trunk (Fig. 7). The greater part of the axial musculature is intact, only the dorsal portion having been cut off. The arrangement of the fibers in the myotomes is normal, except that the individual fibers are often separated from each other by quite large, clear spaces. In the tail the musculature of the two sides arches over the notochord dorsally (Fig. 8), forming a continuous sheet, horseshoe shaped in section. Examination of sagittal sections of embryos which had lived from five to seven days after the removal of the cord corroborates the results of the observations upon the living specimens, as regards the arrangement of the musculature. The division into myotomes is distinct. The primary abdominal muscle is seen as a band of fibers arising from the ventral edge of the myotomes at the base of the tail, skirting past the bud of the hind leg and spreading out anteriorly into a sheet of cells in the abdominal walls. The anterior portion of this muscle is, as is normally the case in this stage, composed of spindle-shaped cells with little or no contractile substance.

While the above account holds for the best specimens, many cases were observed in which there was much irregularity in the arrangement of the muscle fibres. Such irregularities are more marked in the immediate neighborhood of the scar. They are undoubtedly due to a disarrangement of some of the cells at the time of the operation and to uneven healing of the wound.

The study of the muscular tissue with highly magnifying powers reveals in the best instances a perfectly normal differentiation of its elements. From this condition there are to be found all gradations down to that shown in some of the poorer specimens in which the degeneration of the elements is marked. In the injured embryos there is a distinct retardation of the differentiation of the muscle fibres, corresponding to the slower development of the organism as a whole. In a specimen killed three days after the removal of the cord there is thus but a small amount of contractile substance laid down in the myotomes and the muscle cells still contain a large amount of yolk. Cross striations of the fibrils may, however, be made out. In a series of sagittal sections of an embryo killed six days after the operation the differentiation of the muscle fibers shows a marked advance. The yolk spheres are almost 
entirely gone from the myotomes and the fibers are crowded with striated fibrillæ (Fig. 9). The most striking abnormal feature in the individual under consideration is the presence of vacuoles in the axes of the muscle fibers, together with a larger amount of pigment than is usually found. The muscle cells of normal larvæ may, however, show some vacuolization in the axial protoplasm at the time when the absorption of the yolk is about completed. In the injured larva the length of the muscle fibers is not so great as in the normal; many fibers are separated from the neighboring ones by clear spaces. Cross sections of a larva of the same age as the one just described show that the muscle fibers are surrounded by a very delicate membrane, the sarcolemma (Fig. 11). The fibers, which are cut near the end, are filled out entirely by fibrillæ; those cut near the middle show nuclei mostly situated in the axis of the fiber, though sometimes eccentrically placed just beneath the sarcolemma. Vacuoles are also present in the axial sarcoplasm.

The amount of vacuolization shown by the muscle fibers varies considerably in different specimens and even in different regions of the same one. Thus, there are often to be found fibers of perfectly normal appearance, with no vacuoles at all and no other signs of degeneration. Such a fiber, taken from the tail of an individual much like the one shown in Fig. 6, is shown in the accompanying cut (Fig. 10). In the musculature of the limb of the specimen described in the next section there are likewise no vacuoles

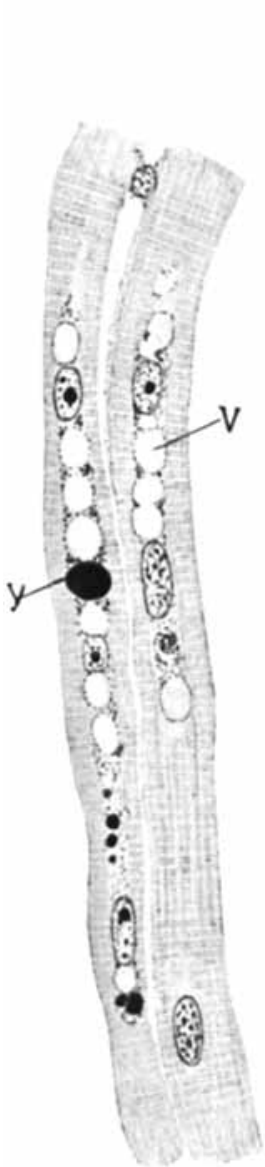

FIG. 9.

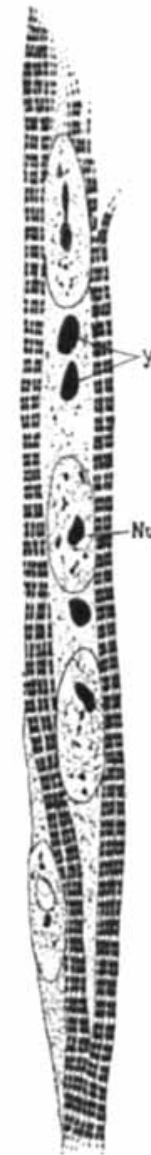

Fig. 10.

Fig. 9. Two muscle fibers from the root of the tail of a larva from which the spinal cord had been removed six days prior to fixation; $v$, vacuole; $y$, yolk spherule.

Fra. 10. Muscle fiber from tail of larva similar to the one shown in Fig. 6. Killed seven days after cutting the spinal cord. This figure has been reduced to the size of Fig. 9 for comparison, though the magnification is much greater. in the fibers. On the other hand, in some specimens there is not only marked vacuolization, but also alteration of the contractile substance and partial arrest of its development. Blotches 
of an almost hyaline substance, which stains intensely with Congo red, are found scattered through the musculature in these cases. These conditions are found also in other parts of the specimen where the nervous system is still in connection with the musculature. They cannot therefore be considered as due to the lack of nervous stimuli but rather to unfavorable accidents of the operation.

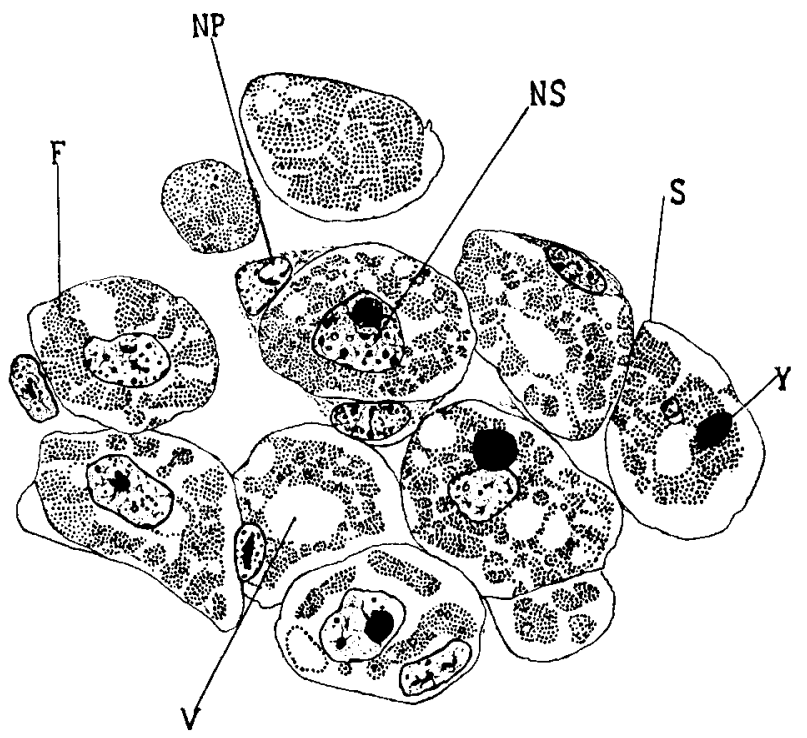

FIG. 11. Muscle fibers in eross section, from the same section as Fig. 7 ; larva shown in Fig. 3. $f$, fibrille; $n p$, nucleus of perimysium internum; $n s$, nucleus of muscle; 8 , sarcolemma; $v$, vacuole; $y$, yolk spherule.

The Development of the Hind Limbs without the Presence of Nerves.

While the foregoing experiments suffice to show that the grouping of the muscle fibers into individual muscles takes place without the influence of the nervous system, it might be urged that this is the case only in the muscles of comparatively simple arrangement, such as the myotomes and their immediate derivatives. It seemed desirable, therefore, to test the power of development of the more complicated musculature of the limbs, when the nerve normally supplying it is prevented from growing into it. At my suggestion Mr. H. L. Langnecker undertook to determine this point.

The experiment was carried out as follows: A horizontal slit was made just below the notochord in the axis of the body of a young embryo, in the region from which the hind limb would develop. The wound 
was prevented from healing by the insertion of a hedge-hog spine for a few hours, until the cut surfaces healed over. The hole made in this way was found to remain open in the majority of instances, and the spinal nerves were thus prevented from growing out into the limb. Such larvæ live readily for a time, but difficulty was experienced in keeping them alive until the time for metamorphosis. One specimen lived, nevertheless, for this length of time. As regards outward form the hind legs developed fully; all of the segments were normal, as was the number of toes. The limbs had, however, an atrophic appearance and no voluntary movements were ever observed, nor could any response to mechanical or electrical stimulation be obtained. Examination of sections failed to reveal the presence of nerves in the hind limb. Cartilage bone and muscle were normally differentiated. The striated contractile substances filled out the nerve fibers, which were, however, of somewhat smaller calibre than in the fore leg in which the nerves were intact. The individual muscles of the hind limb are clearly defined, but it has not been made out as yet whether all of the muscles normally found in the limb are present in this specimen also. The work will be continued during the present season and a full account published by Mr. Langnecker.

\section{The Development of the Embryo in Solutions of Acetone-chloroform.}

For the purpose of drawing or carefully studying living tadpoles it is nearly always necessary to anæsthetize them. Acetone-chloroform has been found to be exceedingly well adapted to this end. It is very easy to manage; a few small crystals added to a watch glass or small dish of water containing the larvæ suffice to stop all voluntary movements, including those of respiration, within a few minutes, while the heartbeat is scarcely affected. The narcosis may be continued as long as desired. On transferring the tadpoles to fresh water recovery takes place quite as rapidly as the narcotization did.

These observations led to the experiment of rearing larvæ under continued narcosis in order to determine the effect of their forced inactivity upon the development of the musculature. It is certain that all functional activity of the muscles is suspended during the action of the drug and also that this is brought about by action upon the nerve centers and not peripherally.

\footnotetext{
${ }^{5}$ It was at the suggestion of Dr. Abel, who first discovered the anæsthetic properties of acetone-chloroform, that I made use of this drug. Miss Randolph, oo, has shown that it is very useful for the narcotization of many kinds of aquatic organisms. The substance is known commercially as "chloretone."
} 
A few preliminary experiments with older larvæ demonstrated that a 0.02 per cent solution, i. e., two parts of acetone-chloroform in ten thousand parts of water is sufficient to narcotize them completely, ${ }^{\text {a }}$ and that the action of the heart is not materially altered. Weaker solutions do not completely inhibit muscular reflexes. Solutions of 0.04 per cent and stronger seriously affect the circulation and ultimately cause death.

After these facts had been determined, the experiments bearing upon the problem to be solved were undertaken. Embryos of each species of frog were placed in similar dishes containing water and solutions of the drug of various known strengths, in order that their development in each might be compared. The embryos selected were all in the same stage of development (Fig. 1) and showed no trace of histological differentiation in the nervous system or musculature. In each experiment care was taken to keep the conditions influencing the different sets of embryos as nearly uniform as possible, varying only the strength of the solution. Owing to the volatility of acetone-chloroform, it was found necessary to keep the dishes containing the embryos closed, and to change the fluid every day or two.

Several factors which had a district influence on the success of the experiments manifested themselves during their course. It was found, in the first place, that the embryos of $\mathrm{R}$. virescens suffer least from the action of the drug. Those of $\mathrm{R}$. palustris are somewhat more susceptible, while sylvatica embryos exhibit a considerably more marked tendency towards deformity. Again, it was found that the deleterious effects of the drug were less marked when the temperature was near the optimum for development, for this permitted the embryos to reach the final stages of development in a minimum time.

The results of the experiments may be summed up very briefly. The embryonic development takes place in solutions of the drug, when care is taken to keep the conditions favorable, in an almost normal manner, although distinctly more slowly than in water. The retardation of the development is directly proportional to the strength of the solution. The results in detail may best be presented by giving the original record of a typical experiment.

\section{EXPERIMENT 6.}

April 20, 1902. Sixteen palustris and seven virescens embryos are put into a 0.03 per cent solution of acetone-chloroform, and eight palustris and three

\footnotetext{
- There is some discrepancy between this result and Miss Randolph's, who makes the minimal dose much stronger. This can perhaps be explained by the rapid volatilization of the substance when kept in open vessels.
} 
virescens embryos into a similar dish containing a solution of the same strength, the latter to be used for testing the irritability. Eight palustris and two virescens embryos are placed under similar conditions in water.

April 22. The temperature has varied between $70^{\circ}$ and $80^{\circ} \mathrm{F}$. In the palustris embryos kept in water the external gills are sprouting and the blood may be seen circulating in them. These embryos react reflexly to mechanical stimuli; i. e., on being touched by a needle, they first contract the opposite side of the body. The drugged embryos are not quite so far along in their development. The heart-beat is distinct, but there is no circulation as yet in the gills. There is a slight swelling in the pericardial region (Fig. 12). The test embryos react locally to mechanical stimuli (direct muscular stimulation).

April 23. The temperature has been above $80^{\circ} \mathrm{F}$. The embryos in the acetone-chloroform solution are developing well. The circulation in the external gills is good. They scarcely give even a local response to stimuli.

April 24. The temperature has been cooler, but above $70^{\circ}$ all day. The drugged embryos are developing normally. There is no reaction to stimuli except a faint local one. The solution is diluted to 0.025 per cent.

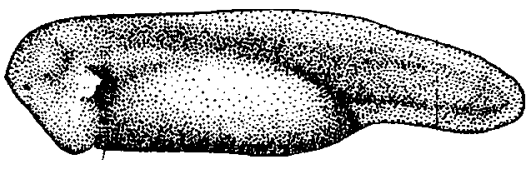

$\mathrm{P}$

Fic. 12.

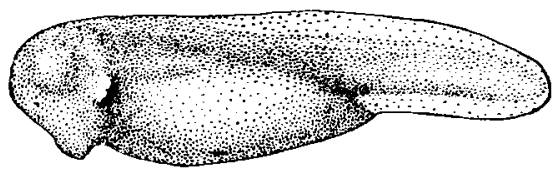

Fia. 13.

Fic. 12. Embryo of $R$. palustris kept two days in a 0.03 per cent solution of acetonechloroform. $\times 9 . P=$ pericardium.

Fia. 13. Control embryo kept two days in water. $\times 9$.

April 25. Temperature this morning, $68^{\circ}$. The circulation is well established in the tails of the palustris embryos. The virescens embroys are not quite so far advanced in their development. There is no reaction to stimuli, except a very feeble local one.

April 26. Solution of drug diluted to 0.02 per cent. The circulation in the tail of the virescens embryos is well established. There is only very slight local reaction to stimuli.

April 27. The control specimens kept in water are now feeding and passing fæces. The drugged embryos are slightly swollen. The coils of their intestines are not wholly normal. The heart action is good. Three palustris and one virescens larve are preserved. The others are put into fresh water for recovery.

4.38 P. M. Larvæ put into fresh water.

4.42. No reaction to stimull.

4.49. Virescens larvæ react with a quiver or jerk. Palustris larvæ do not react at all.

4.55. Virescens larvæ are able to swim across the dish. Jaws are moving.

Gasping respiratory movements. Palustris larvæ do not react.

5.15. Palustris larvæ do not react. 
5.29. Some of the palustris larvæ react with a jerk or two.

545. All of the palustris larvæ react to stimuli. Several able to swim across the dish.

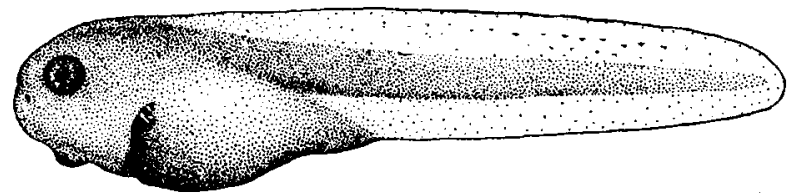

Frg. 14. Embryo of $R$. palustris kept five days in a 0.03 per cent solution of acetonechloroform. $\times 9$.

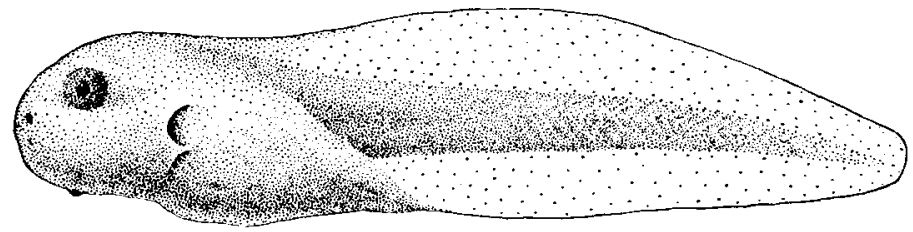

FIG. 15. Control embryo kept five days in water. $\times 9$.

May 6. The recovered tadpoles have been kept in a large aquarium, with plenty of food. The palustris larvæ appear normally formed when seen from above and from the side. One has remained very small. The intestinal coils are not normal. Of the virescens larvæ, two are normal looking, except for the intestinal coils. 'One is very much swollen on the sides, due probably to distention of the Iymph sinuses.

The histogenesis of the muscular tissue was followed in a series of specimens, taken from the above and other experiments and preserved from day to day. The embryos were fixed in mercuric chloride and acetic acid and the sections stained for the most part in Heidenhain's iron hæmatoxylin.

Experiment 6: Palustris embryo two days in 0.03 per cent solution.The muscle cells in the myotomes are normal. They still contain a large amount of yolk but no vacuoles. Contractile fibrillæ are present in considerable quantity.

Experiment 6. Palustris embryo three days in 0.03 per cent solution.Corresponding with the general retardation of development as compared with that of the control embryos reared in water, the development of the individual muscle cells is retarded (cf. Fig. 16 and Fig. 17). There is more yolk in the muscle fibers of the drugged specimen; the striations of the muscle fibrillæ are in corresponding myotomes less distinctly marked. The individual fibers are not so slender as in the normal control. When a comparison is made between the less differentiated myotomes in the tail and those in the trunk of the normal specimen, it is seen that the difference in the clearness of the striations is merely an evidence of the difference in the degree of development. There is a slight vacuolization of some of the muscle fibers in both 
of the embryos. The basis of comparison of the two specimens is rendered all the more exact by the fact that the sections of both were run through the staining fluids simultaneously.

Experiment 6. Palustris embryo, five days.-There is a marked increase in the vacuoles in the axial sarcoplasm of the muscie flbers, while in the control specimen, reared in water, there is but very slight vacuolization.

Experiment 6. Palustris embryo, seven days.-In this specimen the yolk is practically gone. The vacuolization of the fibers of the myotomes is marked. The flbers are separated from each other by clear spaces. The jaw muscles show some vacuolization, but in a much less marked degree than in the myotomes. The striated flbrillar substance is also well marked in the former.

Experiment $\%$ Larvae of six days.-Two specimens, one of which had been kept in a 0.025 per cent solution, and one control reared in water were imbedded side by side and cut and mounted together. The contrast in the muscular tissue in the two specimens is not marked. There is more vacuolization in the drugged larva, Fig. 18 , but this characteristic is much less marked than in the specimen just described. This condition is due in all probability to the circumstance that the solution of the acetone-chloroform was slightly weaker than in the former case, and also to the fact that, owing to the high temperature, the larva had attained its development in six days of exposure to the drug, instead of in seven, as in the former instance.

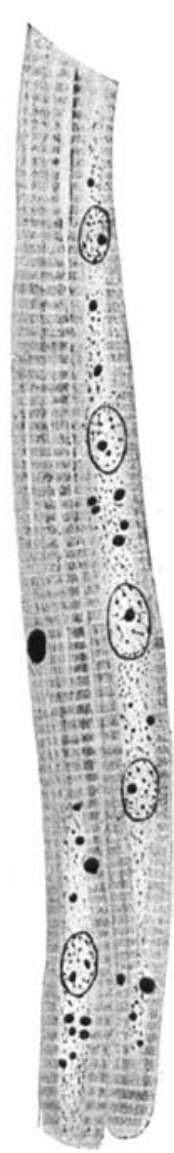

Fia. 16,

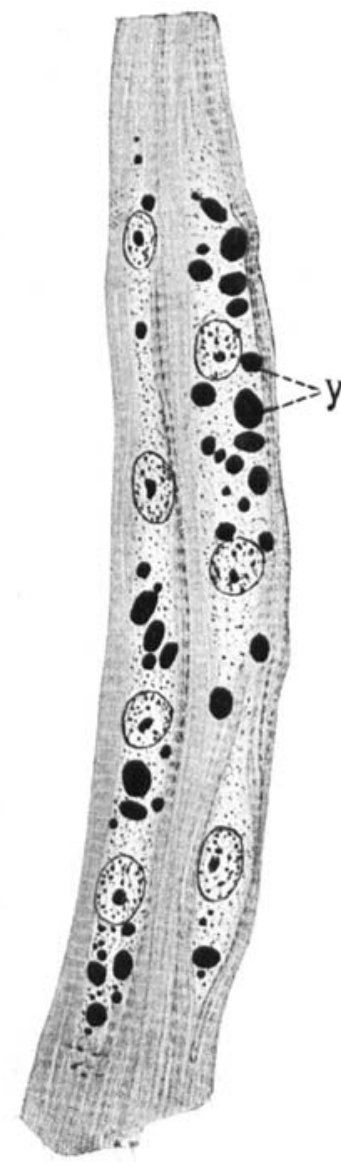

Fra. 17.

Fig. 16. Two muscle thers from the ninth Fra. 16. Two muscle thers from the ninth days older than the stage used in the experiment.

Fig. 17. Two muscle fibers from the myotome of a palustris embryo kept for three days in a 0.03 per cent solution of acetone-chloroform. $y$, yolk spherule.

The most striking feature of the experiment described in full above is the extraordinary rapidity of the recovery from the action of the acetonechloroform; in several other similar experiments the recovery was even more rapid. Thus, in one instance (experiment 1), a virescens embryo, 
reared in 0.02 per cent solution, had in five minutes recovered sufficiently to swim several strokes, and in seventeen minutes the co-ordinated movements of this specimen could not be distinguished from those of a perfectly normal larva. In other cases the recovery of palustris larvæ was

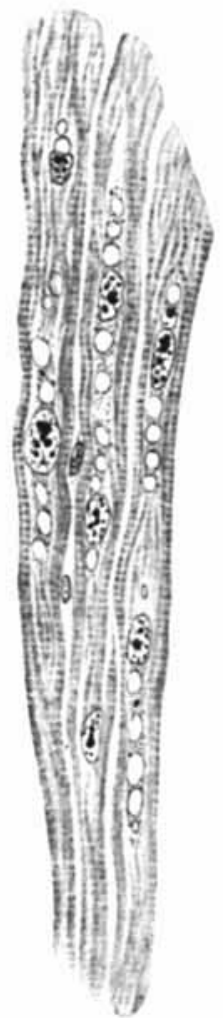

Fig. 18. Muscle fibers from myotome at base of tail of larva kept six days in acetone - chloroform. found to be considerably more rapid than in the experiment just described in full though it was never so rapid as is the case with virescens larvæ. It is clear then that the mechanism requisite for carrying out the complex muscular movements of locomotion and respiration develops normally without ever having functioned, although in the normal development of the embryo, the acquirement of this power is a gradual one, being accompanied by the frequent activity of the parts.

The irritability of the developing embryos was tested in the experiments from day to day by stimulation with a needle-point. No reflex response was ever observed at any stage in embryos reared in solutions of 0.02 per cent, except in a few doubtful instances. Nevertheless it seemed safer to experiment with somewhat stronger solutions ( 0.025 to 0.03 per cent), in which no embryos ever manifested any reflex activity whatever. Electrical stimuli were not tried, but it was observed that the drugged organisms were not sensitive to chemical stimuli, for in putting them into the ordinary fixing fluids, such as mercuric chloride or formalin, no movements were ever observed, while normal embryos contract their muscles violently. The irritability of the muscle itself remains, however, even in embryos kept in the stronger solutions of the drug, but the effect of direct stimulation of the muscles may readily be distinguished from that of the indirect or reflex irritation. The former is evidenced by a sharp tonic contraction of the myotomes on the same side of the body and immediately at the point of application of the needle prick; moreover, this type of contraction takes place only on strong stimulation, often only when the muscle is actually pierced by the point of the needle. The reflex response of normal embryos is quite different from this. If one stimulates a young embryo by lightly touching it on one side of the body, the first response is a general contraction of the myotomes usually on the opposite side of the body, followed by the alternate contraction of the two sides, which results in a co-ordinated 
swimming movement. These experiments afford therefore a corroboration of the conclusion drawn from experiments on higher animals that the acetone-chloroform acts upon the nerve centers and not peripherally.

The general retardation of the development of the drugged organisms results probably in the first instance from disturbances in the metabolism of the cells, possibly in their diminished power of oxidation. It is at least justifiable to assume this in view of our knowledge of the action of related substances, such as chloroform, upon adult organisms. While the external gills of the embryo are functional, this is perhaps the sole cause for the slower development. Later, when the internal gills are developed, the larvæ, which are normally dependent on the respiratory movements for the proper aeration of the blood, must lack an adequate supply of oxygen. This contributes to further delay in development and no doubt is the cause of some of the deviations from the normal course, which manifest themselves more clearly in this late period.

The differences in external form between the normal and the drugged embryos are not great. There is often a considerable effusion of fluid into the pericardial cavity at an early period, causing an unusual swelling in this region (cf. Fig. 12 and Fig. 13) ; and besides, the bodies of the drugged larvæ are usually somewhat swollen. The caudal fin of these specimens fails to expand as fully as in normal ones (cf. Fig. $1 \dot{4}$ and Fig. 15). The cedema and the pericardial effusion are no doubt due to weakened heart action, and this may affect also the circulation in the tail to some extent, resulting in a slight arrest of development. The vacuoles, which form in the axial sarcoplasm of the muscle fibers, may also be accounted for by disturbances in the circulation.

\section{Discussion of THE Results.}

In the first series of experiments described above, the spinal cord of the embryo was removed before the histological differentiation in either the muscular or the nervous tissue had begun. From the very beginning of the visible changes in structure, which transform a simple mesodermal cell into a muscle fiber, the isolation of the musculature from the nervous system was complete. All chance for the exertion of any peculiar formative stimulus emanating from the nervous system as such was eliminated; and likewise, owing to the consequent paralysis of the muscles in question, any possible stimulus resulting from the functional activity of the muscle itself was excluded. Still the differentiation of the contractile substance took place in normal manner, as did the groupmig of the fibers into individual muscles. Just as Schaper's experiments have shown that the brain as a nerve center exerts no general formative 
influence upon the development of the organism as a whole, the present experiments demonstrate that the nerve elements normally innervating a muscle play no part in its morphogenesis.

This experimental demonstration of the independence of the developing muscular tissue may be regarded as crucial evidence against the general correctness of the view held by Neumann, or and $\mathbf{0}_{3}$, that the first development of the muscles takes place under the influence of the nervous system through the agency of the motor nerves. Herbst's, or, assumption of a formative stimulus proceeding through the sensory nerves is also shown to be erroneous. Of course there is the possibility to be considered that the conditions obtaining in mammals differ, in regard to the action of the nervous system, from those in the frog; but this is not likely, and in view of the relative activity of the developing tadpole, as compared with the mammalian fœtus, any differences between the two would most likely be in favor of a more important influence being exerted by the nervous system in the former than in the latter.

The second series of experiments is like the first in that the effect of possible functional stimuli is entirely eliminated, although the possibility still remains that special formative or trophic stimuli, if such exist, are not interrupted by the action of the acetone-chloroform. While, therefore, the latter experiments are in themselves not so conclusive as the former in proving that the histological differentiation of the musculature is independent of the action of the nervous system, the similar results in the two series would indicate that the two methods of elmination of nervous action, the operative and the chemical, are as a matter of fact equivalent. The experiments with acetone-chloroform have the additional value that the function of the nervous system may be restored by the removal of the drug from the organism. In this way the functional power of the complex nervous and muscular mechanisms, which carry out the movements of swimming and respiration, may be tested. The surprisingly quick recovery - or better, since the musculature had never shown any activity - the quick acquisition of the power to carry out these movements, shows that the mechanisms in question develop in perfect order, without the influence of normal function in each successive stage. The organism in which this takes place is one which is normally very active, and one in which the power of locomotion is only gradually acquired. While the above fact cannot but strike one as remarkable, it is, nevertheless, on the other hand, in accordance with what should in reality be expected, for such complex mechanisms as, for example that used in respiration, develop in the mammallian embryo during intrauterine life without ever having been brought into action. 
While it has been emphasized in the foregoing that the building up of the musculature takes place normally even in the absence of connection with the nervous system, it is not to be lost sight of, that in all of the experiments certain signs of interference with normal development and of degeneration make themselves apparent. The general retardation of the development of embryos reared in acetone-chloroform may, however, be accounted for, as pointed out above, by the direct action of the drug upon metabolism and upon the heart. The most noticeable degenerative change in the embryonic muscle, the appearance of vacuoles in the axial sarcoplasm, may also be explained as due to disturbances in the circulation. That the vacuolization of the embryonic fibers is not due specifically to the removal of nervous influence is shown clearly by the fact, to which Dr. Knower has called my attention, that an exactly similar condition supervenes in the musculature of frog embryos from which the heart had been removed at an early stage. Much of the interference with the normal processes of development may therefore be set down as due to influences other than the changed relations with the nervous system, though it is not impossible that the disturbances are due to some extent to the latter cause. This would not be remarkable, however, in view of the well-known fact that in the adult a muscle undergoes atrophy after its nerve supply is cut off.?

We must, in fact, consider the embryo not merely as a developing organism, in which the parts are important potentially, but also as an organism, which in each stage of development has functions to perform that are of importance for that particular stage. If these functions are interrupted, as they are in the present experiments, we can but expect to find, that side by side with the constructive processes which build up a muscle fiber out of an undifferentiated muscle cell, and which, as the experiments show, take place quite independently of the nervous system or the stimulus of function, there also take place certain degenerative changes due to the absence of these influences. The results of experi-

The morphological changes which take place in a muscle after neurotomy have been the subject of numerous investigations, of which a full review has been given by Stier, 97. The most pronounced changes are diminution in the caliber of the fibers and proliferation of the sarcolemma nuclei. Ricker and Ellenbeck, 99, find also vacuolization of the fibers and other signs of œdema. Ricker, or, explains the changes which take place as due primarily to the interference with the normal working of the vasomotor apparatus

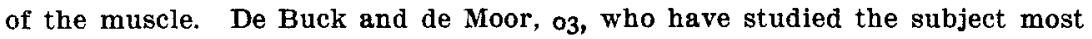
recently, emphasize the regressive changes of the muscle fiber itself, i. e., its return to the embryonic condition, and consider the changes to be due to the lack of functional stimuli.

$$
\text { in }
$$


ments on the sense organs of the lateral line, after destruction of their nerve supply, ${ }^{8}$ bear out the correctness of this view.

Long ago Roux, 8I and 85, suggested that the development of the organism could be divided into two periods, the one an organ-forming period and the other one of functional development. In the first the organs are formed and brought to that condition in which they are capable of beginning a specific function; in the second period, in which the organs exercise their specific function, their further perfection is helped by this activity and interfered with by its absence. While the general aptness of this distinction is apparent, the present study shows that there is not only an overlapping of the two stages in different systems of organs, as Roux pointed out, but also in the same organs; even in one and the same muscle fiber, as shown above, the tendencies of the two periods may mani. fest themselves side by side. It must nevertheless again be emphasized that all of the constructive processes involved in the production of the specific structure and arrangement of the muscle fibers take place independently of stimuli from the nervous system and of the functional activity of the muscles themselves.

\section{LIST OF REFERENCES.}

Bardeen, Charles Russell, oo.-The Development of the Musculature of the Body Wall in the Pig, including Its Histogenesis and Its Relations to the Myotomes and to the Skeletal and Nervous Apparatus. The Johns Hopkins Hospital Reports, Vol: IX.

- o2.-Embryonic and Regenerative Development in Planarians. Biological Bulletin, Vol. III.

- - o3.-Factors in Heteromorphosis in Planarians. Archiv für Entwickelungsmechanik, Bd. 16.

Barfurth, Dietrich, ox.-Ist die Regeneration vom Nervensystems abhängig? Verhandlungen der Anatomischen Gesellschaft, Bonn, 1901. Anatomischer Anzeiger, Bd. 19.

Buck D. DE et Moor, L. DE, o3.-Morphologie de la Régression Musculaire. Le Névraxe, Vol. 5.

Driesci, H., or.--Neue Antworten und neue Fragen der Entwickelungsphysiologie. Ergebnisse der Anatomie und Entwickelungsgeschichte, Bd. 11, 1901.

Fraser, A., 95.-Various Morphological Papers, III. On Various Single and Double Monstrosities, with Remarks on Anencephalic and Amyelic Nervous Systems. Trans. Royal Academy of Medicine, Ireland, Vol. 12. (Cited according to Schaper.)

Harrison, Ross G., 03.- On the Differentiation of Muscular Tissue when Removed from the Influence of the Nervous System. Proc. Ass. Amer. Anatomists, American Journal of Ajatomy, Vol. 2.

\footnotetext{
${ }^{8}$ Harrison, o3a, p. 72.
} 
Harrison, Ross G., o3a.-Experimentelle Untersuchungen über die Entwicklung der Sinnesorgane der Seitenlinie bei den Amphibien. Archiv für mikroskopische Anatomie, Bd. 63.

Herbst, CuRT, 99.-Ueber die Regeneration von antennenähnlichen Organen an Stell von Augen. Archiv für Entwickelungsmechanik, Bd. 9.

- ora.-Ueber die Regeneration von antennenähnlichen Organen an Stell von Augen, V. Weiter Beweise für die Abhängigheit des Qualität des Regenerates von den nervösen Centralorganen. Archiv für Entwickelungsmechanik, Bd. 13.

or.-Formative Reize in der thierischen Ontogenese. Leipzig, 1901.

Leonowa, O. v., 93.-Zur pathologischen Entwickelung des Centralnervensystems. (Ein Fall von Anencephalic combinirt mit totaler Amyelie.) Neurologisches Centralblatt, Jahrg. 12.

LOEB, J., 96.-Hat das. Centralnervensystem einen Einfluss auf die Vorgänge der Larvenmetamorphose? Archiv für Entwickelungsmechanik, Bd. 4.

Morgar, T. H., or.-Regeneration. New York, 1901.

Neumaxi, E., or.-Einige Bemerkungen über die Beziehungen zwischen den Nerven und Muskeln zu den Centralorganen beim Embryo. Archiv für Entwickelungsmechanik, Bd. 13.

- o3.-Uber die vermeintliche Abhängigheit der Entstehung der Muskeln von den sensibeln Nerven. Archiv für Entwicklungsmechanik, Bd. 16.

Nussbaum, M., 94.-Nerv und Muskel: Abhängigheit des Muskelwachsthums vom Nervenverlauf. Verhandlungen der Anatomischen Gesellschaft. Versammlung in Strassburg, 1894.

- o2.-Nerv und Muskel. Ergebnisse der Anatomie und Entwicklungsgeschichte, Bd. 11, 1901.

Randolph, HaRIET, oo.-Chloretone (Acetonchloroform), an Anæsthetic and Macerating Agent for Lower Animals. Zoologischer Anzeiger, Bd. 23.

RICKER, G., or.-Beiträge zur Lehre von der Atrophie und Hyperplasie. (Nach experimentellen Untersuchungen am Muskel.) Virchow's Archiv, Bd. 165 .

RICKeR, G., and Ellenbeck, J., 99.-Beiträge zur Kenntniss des Veränderungen des Muskels nach der Durchschneidung seines Nerven. Virchow's Archiv, Bd. 158.

Roux, W., 8x.-Der züchtende Kampf der Theile oder die "Tneilauslese" im Organismus. Gesammelte Abhandlungen, Bd. I, Leipzig, 1895.

- 85.-Beiträge zur Entwickelungsmechanik der Embryo, III. Ueber die Bestimmung der Hauptrichtungen des Froschembryo im Ei und über die erste Theilung des Froscheies. Ibid., Bd. II.

Rubin, Richand, 03.-Versuche über die Beziehung des Nervensystems zur Regeneration bei Amphibien. Archiv für Entwickelungsmechanik, Bd. 16.

Schaper, Alfred, 98.-Experimentelle Studien on Amphibienlarven. Erste Mittheilung: Haben künstlich angelegte Defekte des Centralnervensystems oder die vollständige Elimination desselben einen nachweisbaren Einfluss auf die Entwickelung des Gesammtorganismus junger Froschlarven. Archiv für Entwickelungsmechanik, Bd. 6. 
220 Relation of Nervous System to the Developing Musculature.

Stier, Siglinde, 97.-Experimentelle Untersuchungen über das Verhalten der quergestreiften Muskeln nach Läsionen des Nervensystems. Archiv für Psychiatrie und Nervenkrankheiten, Bd. 29.

WEBER, E. H., 5x.-Ueber die Abhängigheit der Enstehung der animalischen Muskeln von der animalischen Nerven, erlautert durch eine von ihm und Eduard Weber untersuchte Missbildung. Archiv f. Anatomie, Physiologie und Wissenschaftliche Medicin, Jahrg., 1851.

WolfF, Gustay, 02.-Die physiologische Grundlage der Lehre von den Degenerations-zeichen. Virchow's Archiv, Bd. 169. 